\title{
Economic evaluation of small desalination plants from brackish aquifers. Application to Campo de Cartagena (SE Spain)
}

\author{
J. Aparicio $^{\mathrm{a}, \mathrm{b}, *}$, L. Candela $^{\mathrm{b}}$, O. Alfranca ${ }^{\mathrm{a}}$, J.L. García-Aróstegui ${ }^{\mathrm{c}}$ \\ a Department of Agri-Food Engineering and Biotechnology, Technical University of Catalonia, ESAB, Av. Canal Olimpic, s/n, 08860 Castelldefels, Spain \\ ${ }^{\mathrm{b}}$ Civil and Environmental Department, Technical Univ. of Catalonia-UPC, Gran Capitan s.n., 08034 Barcelona, Spain \\ ${ }^{c}$ Instituto Geológico y Minero de España (IGME), Avda. Miguel de Cervantes 45, $5^{\circ}$ A. Edificio Expo Murcia, 30009 Murcia, Spain
}

2017

Accepted 9 February 2017

Available online $\mathrm{xxx}$

\section{Introduction}

In recent years, the Mediterranean area has witnessed an increasing water shortage trend, mainly due to: increasing population and tourism (especially in coastal areas), new agricultural developments, decreased rainfall and water management issues [1]. In some Mediterranean areas, precipitation is lower than $300 \mathrm{~mm} /$ year; the temporal variability of precipitation controls and affects both the quantity and quality of water resources, and is a source of freshwater availability inequalities. Droughts, as a result of temporal precipitation irregularities, are common in all areas and lead to lack of temporal water resources [2].

In a number of Mediterranean basins, one of the main challenges is to secure a reliable water supply in both quantity and quality terms in order to guarantee sustainable use and enough resources, even during long inter-annual dry periods [3]. In Spain, some technical and non-technical solutions proposed for the different Basin Plans [4] range from water transfers, public participation, economic measures, water saving, aquifer recharge, the development of new water supply sources (as seawater/brackish water desalination) to a more flexible water management system implementation according to Integrated Water Resources Management (IWRM).

Desalination (from seawater or brackish aquifers) has generally become an extensively applied solution for an increasing number of regions around the world and is considered one of the most sustainable solutions to the water scarcity problem [5-7]. In recent years, the advances made in Reverse Osmose (RO) technology have been such that this technique is being used in almost all new plant designs being constructed worldwide. Seawater desalination costs remain high and they have been rarely considered for agricultural purposes, except for

\footnotetext{
* Corresponding author at: Department of Agri-Food Engineering and Biotechnology, Technical University of Catalonia, ESAB, Av. Canal Olímpic, s/n, 08860 Castelldefels, Spain.
}

highly profitable crops and greenhouses [8]. However, continuous technological development, along with improving energy consumption, have increased the building of private small brackish water desalination plants [9].

In comparison with seawater [8], brackish water has lower dissolved salts, which makes the life span of membranes longer. As a result, this has led to the exploitation of saline continental aquifers in southern European Mediterranean countries [10] particularly in Campo de Cartagena (the Segura Basin) in southeast Spain. Campo de Cartagena is one of Europe's driest areas (precipitation around $300 \mathrm{~mm}$ ). However, given the high quality of land and its mild climatic conditions, it has excellent aptitudes for very competitive agriculture, devoted largely to exports and to domestic food supplies [11]. As water availability is lacking and groundwater quality is poor, which impairs its direct use for irrigation, the agricultural sector has developed private small groundwater desalination plants $\left(15-20 \mathrm{~m}^{3} / \mathrm{h}\right)$ to ensure water availability for its crops [12]. This agricultural management is most relevant in the region, mainly due to the continued growth of these facilities in recent years, and their strong social, economic and environmental impact.

Economic evaluation project techniques are an instrument to calculate the costs and benefits related to the decision process in water resources projects, including water desalination plants [13]. Conventional methodologies of project economic analyses, such as the Cost-Benefit Analysis (CBA), are currently applied to compare the economic feasibility associated with the implementation of different project proposals. The CBA starts from the premise that a project should only be accepted, economically feasible, if all the benefits exceed any incurred costs. Although the management of small plants is well-known, information on the desalinated water cost is limited; its final cost is highly variable and appears to be quite site-specific as the cost per cubic meter varies from one installation to the next [14]. As a result, small desalination utilities have been used in most cases, and are implemented without considering any economical evaluation. 
This research assesses by CBA and sensitivity analyses the economic performance of three small reverse osmosis (RO) desalination plants, with different characteristics, that operate distinct wells by exploiting the brackish aquifers located in Campo de Cartagena. The primary objective is to assess the water cost for the agricultural irrigation of citrus crops and associated benefits.

\section{Study area}

\subsection{The Campo de Cartagena}

The Campo de Cartagena basin, located in southeast Mediterranean Spain (Fig. 1), is a $1440-\mathrm{km}^{2}$ plain with elevations ranging between sea level and 1065 m.a.s.l. From the hydrological point of view, it is composed of 35 subcatchments, with sizes ranging from $0.2 \mathrm{~km}^{2}$ to $696 \mathrm{~km}^{2}$. No permanent watercourse exists and the hydrographic network consists of a number of ephemeral streams that drain to the Mar Menor hypersaline lagoon. To the South and East, the area is limited by the Mediterranean Sea, and by low mountain ranges to the north and west. The region is characterized by a semiarid Mediterranean climate, with an average temperature of $18{ }^{\circ} \mathrm{C}$ and $300 \mathrm{~mm}$ of annual rainfall distributed unevenly into a few intense events, which are highly variable in space and time [11]. From the geologic standpoint, the Neogene and Quaternary sediments of the Betic Cordillera laid unconformable over highly fractured metamorphic rocks of mainly the Triassic age.

The population's water supply relies mainly on groundwater resources and the Tajo-Segura water transfer, which began in 1980 and transfers water from the Tajo basin (central Spain) to the study area. $>2000$ boreholes/wells for groundwater exploitation, principally for agricultural purposes, are found in the area. Water resources from desalination plants have markedly increased since 2005 [15]. In recent years, water scarcity has increased due to growing demand and seasonal droughts, and even supply constraints, which occurred in August 2003 and led to 12-hour restrictions being applied to 21 municipalities, with $>200.000$ inhabitants in the area [16].
Agriculture is the primary land use with 17,968 ha in 2014 (Fig. 2). Drip irrigation is widely used in the region due to scarce water resources and the need for water conservation [17]. Land use distribution in Campo de Cartagena is heterogeneous, with woody crops (lemon, orange, mandarin, olive, vineyards) and herbaceous crops (mainly vegetables) that cover $>15.977$ ha. (See Fig. 3.)

In order to overcome water shortages in the agricultural sector, farmers have chosen to finance and install small private plants (water comes from brackish aquifers, which is unsuitable for direct irrigation) to thus ensure water availability for their crops. Although an inventory of small plants does not exist, information collected from field campaigns estimates that $>1000$ utilities may exist, the oldest of which were built in the late 1980s. Irrigation is carried out with a mixture of desalted brackish groundwater and water from existing aquifers and/or surface water from the Tajo-Segura transfer, whenever available. This procedure allows farmers to comply with the water quality requested for the different crops being cultivated [12].

\subsection{Hydrogeological framework}

The groundwater hydrology of Campo de Cartagena consists of a sedimentary multilayer complex aquifer composed of marls, limestones, sands and conglomerates that overlay the basement. The hydrogeological system is constituted by deep confined aquifers from Tortonian, Messinian and Pliocene ages and an unconfined Quaternary-aged shallow aquifer. Carbonate rocks of the Triassic-Permian age, which outcrop in the center and on the western border of the plain, also constitute a local aquifer [18]. The upper aquifer extends over $1135 \mathrm{~km}^{2}$ and comprises Quaternary detrital sediments (mainly sands and silts). Average thickness is around $50 \mathrm{~m}$ and the water table is approximately $15 \mathrm{~m}$ deep. The Quaternary aquifer presents contamination by agrochemicals from irrigation return flows; salinity ranges between 2000 and $6000 \mu \mathrm{S} / \mathrm{cm}$. The nitrate concentration in wells exceeds $50 \mathrm{mg} / \mathrm{L}$, and is even higher than $200 \mathrm{mg} / \mathrm{L}$ during some periods. The deep Pliocene confined aquifer, with a lower salinity, also covers most of the plain.

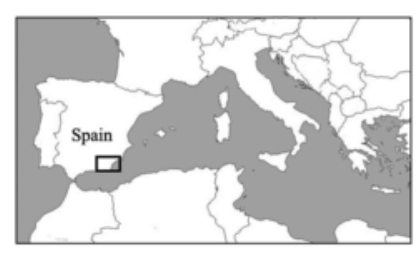

\section{Campo de Cartagena}

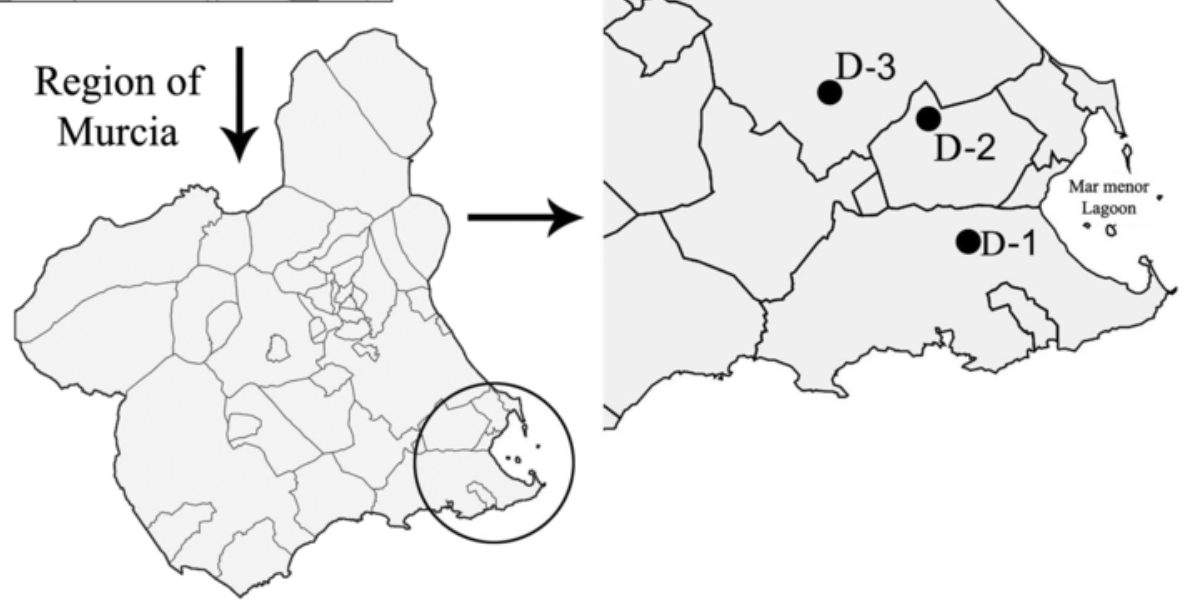

Fig. 1. The Campo de Cartagena study area location. The D-1 to D-3 small desalination plants under study. 


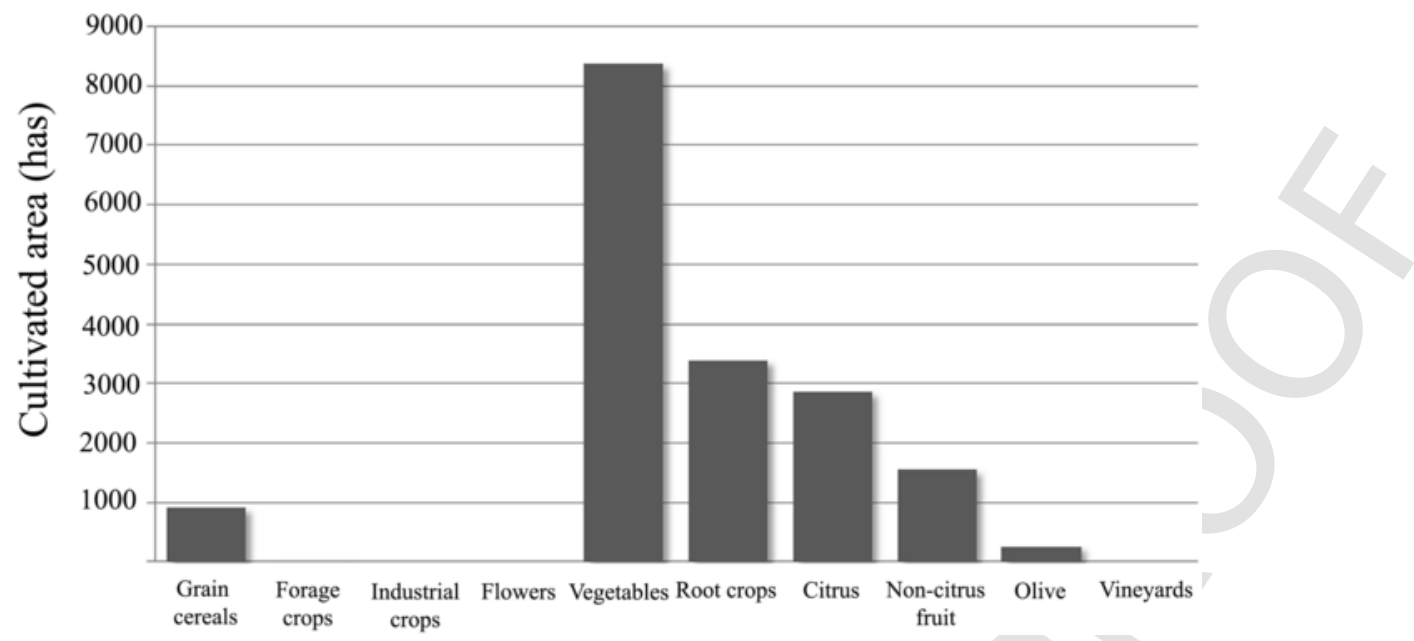

Fig. 2. Hectares of cultivated land and type of crops 2014.http://www.carm.es/econet/sicrem/PU_CartagenaCifrasNEW/P8004/sec4.html.
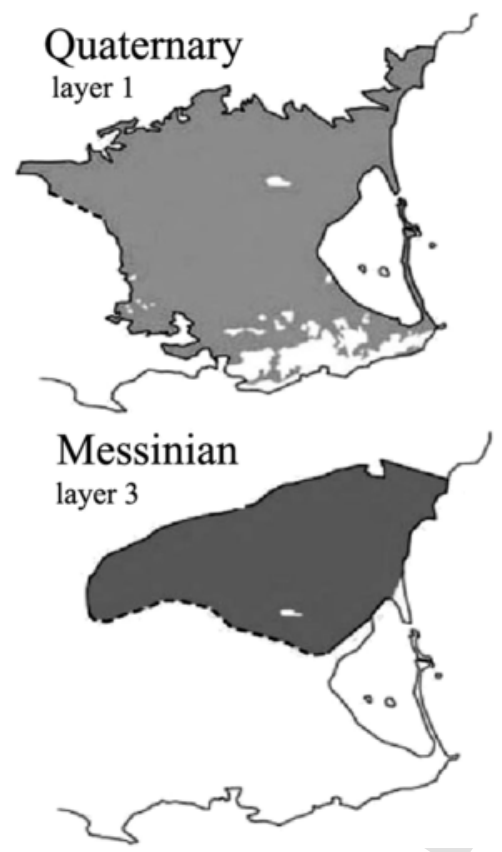
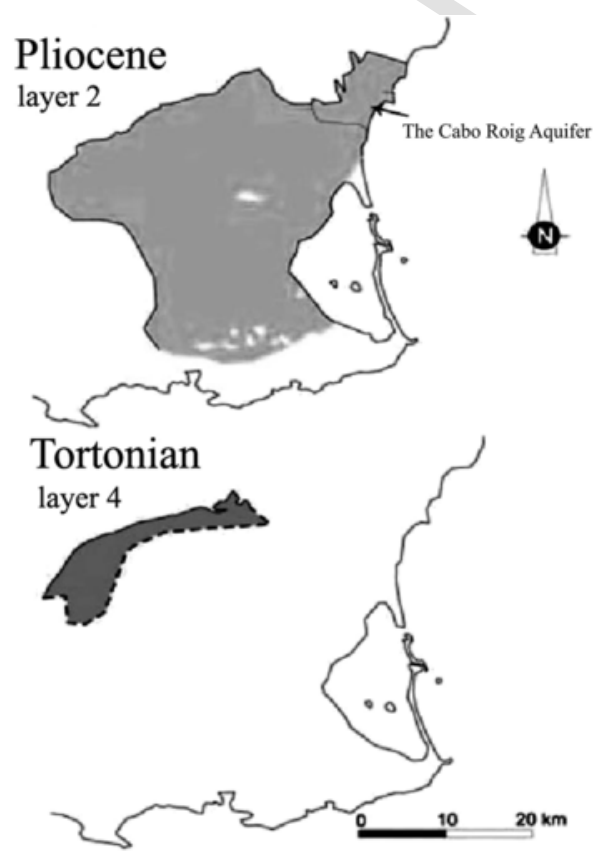

Fig. 3. Geological sketch of Campo de Cartagena [18].

\subsection{Agricultural management of desalted water}

Besides the large desalination plants in the study area administrated by the Water Authority, farmers have promoted the use of small private plants (between 15 and $20 \mathrm{~m}^{3} / \mathrm{h}$ ) based on RO technology. Since the 1990s in the Cartagena region, small desalination plants have been built, and have steadily increased since 2001 due to low operating costs. Most building activity took place in 2005 and later, due to cost reductions and the intense droughts in the area; the year 2005 was the second driest year since 1995 (http://www.aemet.es/).

The management of small desalination plants for agricultural purposes consists of a well intake, a pond and a desalination plant, all located in the irrigated field or nearby. Already existing agricultural wells formerly used in irrigation, when groundwater quality was suit- able for crop irrigation, are used. Only a small number of wells have been drilled for this purpose, but no data are available. Farmers' management of small plants is shown in Fig. 4.

Common irrigation management finally obtains water with the required salinity for each specific crop; this practice is well-known in the area as "Water à la carte". The procedure consists of groundwater desalination from pumping wells (mainly from Quaternary and Pliocene brackish inland aquifers) and stored in a pond. Later, water is mixed with water pumped directly from the aquifer, water from the Tajo-Segura water transfer, or water from a sea-desalination plant, depending on availability, to meet the required salinity concentration.

The salt, minerals, and other compounds produced as a by-product of desalination (hyper-saline brine), are collected through a conveyor managed by local authorities, and are finally discharged into coastal waters through a brine-specific outfall. However, the existing infrastructure is unable to receive all the brines rejected from the area, or 
is in a bad shape, which leads to uncontrolled leakage at certain locations. Consequently, impacts on soil and groundwater by the high salt content may occur.

\section{Data and methods}

An intensive search of the available literature, current research underway in the area and other sources of information, was done. Information was collected from the Water Administration (Confederación Hidrográfica del Segura), private companies, water users (the Campo de Cartagena Farmers Association) and other stakeholders (IGME).

Three field campaigns were run to collect in situ information on the operation of desalination plants and costs through a semi-structured questionnaire. Campaigns took place in November 2014, May 2015 and March 2016. Field campaigns provided relevant information that helped selection of representative small desalination plants to assess the agricultural management carried out in the area.

\subsection{Selecting small desalination plants}

For the final selection, the following criteria were adopted:

(1) Aquifer under exploitation. Groundwater supply comes from wells pumping water from the three existing aquifers in the area (Quaternary \& Pliocene, Messinian and Tortonian). Each aquifer presents a different water quality, salinity concentration and groundwater level depth.

(2) Source of water mixture. The final irrigation water is a mixture of desalted water and water from surface water from the water transfer, sea-desalination and water from the aquifer.

(3) Irrigated crop. Citrus (lemon, orange and tangerine) was the irrigated crop selected at each facility for cost-benefit purposes.

\subsection{Cost-benefit analysis, $C B A$}

Cost-benefit analysis methods are commonly applied when a diversity of projects exists and a decision needs to be made. In short, CBA methods are based on the net profit calculation for each possible project choice. This selection is based on the difference between revenues (the amount of money from citrus sold, as in the proposed case), and the costs needed to be supported by the owner. A common example of costs in desalination plants should include, for instance, capital costs, operating costs, maintenance costs or life cycle costs. Conventional CBA methods usually take into account financial analyses, with a market value. This approach commonly uses both operating and capital costs $[19,20]$.

Since CBA concept is that a project should be done only if the benefits exceed the costs, $(N P)$, all benefits are compared with theirs costs by using a common methodology for economic analyses (Eq. 1) [21]

$$
N P=B_{1}+B_{2}
$$

where, $N P=$ net profit (total income-total costs); $B_{1}=$ total internal benefit (internal income-internal costs) and $B_{2}=$ total external benefit (positive-negative, not considered in this study). The total internal benefit includes citrus sales benefit or profits for each farmer from citrus production, while internal costs are investment cost, annual volume of desalinated water operational and maintenance costs. A project is economically feasible only if $N P>0$. The best option always offers the highest net profit [22-24].

When conducting cost-benefit analysis on a project, a more accurate result is obtained by converting all future costs and benefits to their present values. As the NP needs to be expressed in current values, an effective and widely used approach is the Net Present Value (NPV), one of the most important tools applied in water project analyses given its versatility [25]. The $N P V$ summarizes the values of economically relevant costs and benefits over a project's life span as follows:

$$
N P V=\sum_{t=1}^{T} \frac{N P_{t}}{(1+r)^{t}}
$$

being, $N P_{t}$, = net profit at year $t ; t=$ the relevant year; $r=$ discount rate or interest rate paid for using borrowed funds and $T=$ project lifespan.

The $N P V$ is a measure whether a project is profitable or not: a negative value implies non-feasibility. It is important to mention that lifespan selection is always controversial $[21,26]$; for the small desalination plants, and according to data provided by the three field campaigns, a lifespan of 25 years $(T)$ is defined.

A classical CBA estimates the equivalent money value of the benefits and costs of projects in order to determine the viability and justification of the investment funds allocation. The Benefit-Cost ratio $(B C r)$ can be understood as the present value of benefits divided by the present value of costs, and is calculated as:

$$
B C r=\frac{\sum \frac{B_{t}}{(1+r)^{t}}}{\sum \frac{C_{t}}{(1+r)^{t}}}
$$

where, $B_{t}=$ the benefit at time $t, \mathrm{C}_{\mathrm{t}}=$ the cost at time $t$.

If $B C r>1$, the investment could be economically profitable; if $B C r<1$, the investment should be redesigned or abandoned [27].

The financial viability of the analyzed system was also assessed through the Internal Rate of Return (IRR). The IRR is a discount rate that makes the $N P V$ of all cash flows from a particular project equal to zero, describes by how much cash inflows exceed cash outflows on an annualized percentage basis by taking into account the timing of those cash flows. It equates the discounted future cash outflows (money paid out as a result of its operating activities or investment activities) with initial inflows (money received as a result of its operating activities). The IRR calculations rely on the same formula as NPV does.

$$
\mathrm{NPV}=\sum_{t-1}^{t} \frac{N B t}{(1+I R R)^{t}}+N B_{0}=0
$$

where $N B_{0}=$ initial investment costs, $N B_{t}=$ net cash inflow for period $t, I R R=$ internal rate of return and $\mathrm{t}=$ time period.

Generally, the higher a project's internal rate of return, the more desirable it is to undertake the project; the project with the highest IRR is probably considered the best. The IRR is calculated through either trial-and-error, or using specific software.

The CBA methodology to estimate $N P V$ and $I R R$ is applied to the selected desalination plants to obtain the $\mathrm{m}^{3}$ cost of water. Finally, in order to assess project profitability according to different costs, a $N P V$ (Eq. 2) sensitivity analysis based on the cost of desalinated water between $0.57 € / \mathrm{m}^{3}$ and $3 € / \mathrm{m}^{3}$ was carried out. $N P V$ values were obtained by fixing the final cost $\left(€ / \mathrm{m}^{3}\right)$ while changing operational and maintenance cost values. 


\subsubsection{Total internal benefit calculation, $B_{1}$. Study site}

Total Internal benefit (see Eq. 1) is the difference between internal costs and internal incomes and defined as follows:

$$
B_{1}=\sum S P C-(I C+O M C)
$$

where, $B_{1}=$ internal benefit ( $€ /$ year); $S P C=$ selling price of citrus gross production $(€ /$ year $) ; \quad I C=$ investment cost $(€ /$ year $)$ and $O M C=$ operational and maintenance costs $(€ /$ year $)$.

Operational costs, parameters and variables definition and estimation for small desalination plants $\left(15-20 \mathrm{~m}^{3} / \mathrm{h}\right)$ are based on in situ interviews and similar studies in other areas [28-30]. IC costs $(€)$ provided by the plant owner include land acquisition, desalination plant construction ( $T=25$ years), civil works, electromechanical equipment and pond construction. $O M C$ term includes the electrical energy (power consumption and energy price), labor work $\left(€ / \mathrm{m}^{3}\right)$, chemical products $\left(€ / \mathrm{m}^{3}\right)$, maintenance $\left(€ / \mathrm{m}^{3}\right)$, replacement of membranes $(€)$ and others $\left(€ / \mathrm{m}^{3}\right)$.

Power consumption depends on the size of the plant and includes well pumping, energy consumption, the RO process and transport to the regulatory mixing tank for irrigation. It depends on the amount of time used, the specific energy consumption and the type of distribution contract with the electric power facility.

In large plants the payroll (personnel cost) includes permanent staff for facility operations. However, small desalination plants are easy to handle and do not require a very specialized knowledge. In the study case, farmers are totally in charge of the plant, as in similar Mediterranean areas. In Gaza [32] local operators of small RO plants run their plants with minimum requirements.

Maintenance costs, usually estimated by plant operators, depend largely on plant size, age and location. Generally, it is an annually fixed cost accounting for around $1-1.5 \%$ of the total installed cost for a medium-sized plant.

Other factors considered for cost calculation are:

(1) Salinity and quality of feed water. Low water salinity allows lower power consumption for further treatment, a higher recovery rate and a lower cost per $\mathrm{m}^{3}$ produced.

(2) Plant desalination capacity. The higher the plant's production capacity, the lower the cost of $\mathrm{m}^{3}$ produced.

(3) Origin of water for desalination. This depends on the type of aquifer, and on the depth and quality of water to be treated.

The applied depreciation of the investment cost (IC) was 4\%; This value is common for this type of desalination projects [31,29].

$S P C$ (benefits/incomes, $€)$ : It refers to citrus gross production $(\mathrm{kg} /$ ha) and average price for the 1998-2004 period. It was assumed that cultivated orchards were at full production. Total profit, or farmer income, is the yield per hectare obtained, estimated from the crop's sale price. This approach provides results on the economics of individual subsystems and the system as a whole [33].

It is important to note that finally costs estimation included the desalinated water direct cost $\left(€ / \mathrm{m}^{3}\right)$ and the final 'Water à la carte' cost, after mixing desalted water with the water from different sources (water transfer, groundwater and desalinated seawater).

\section{Results and discussion}

\subsection{Selected plants. Total cost and benefit for citrus irrigation}

Three small desalination plants (D-1, D-2 and D-3; Fig. 1) were finally selected for the cost-benefit analysis. The plants' characteristics are summarized in Table 1 and the geographic location is illustrated in Fig. 1

The final groundwater desalination cost for the selected plants (Table 2; IC, $O M C$, Eq. 5), after taking into account the plant's depreciation cost $(4 \%)$, was $0.57 € / \mathrm{m}^{3}, 0.61 € / \mathrm{m}^{3}$ and $0.70 € / \mathrm{m}^{3}$ for $\mathrm{D}-1$, D-2 and D-3, respectively. The different costs reflect the specific differences among the desalination plants; e.g., groundwater depth, electrical conductivity of the water to be treated, hours of operation per year, etc. Compared to other results for desalinated seawater [29,32], the low cost obtained in this work is due basically to the lower salinity of brackish water (salinity between $3500 \mu \mathrm{S} / \mathrm{cm}$ and $6000 \mu \mathrm{S} / \mathrm{cm}$ ), and also to a low production capacity, which implies lower energy consumption. This is an important fact as energy represents around $44 \%$ of operating costs $[34,35]$.

Table 1

Main characteristics of the three selected desalination plants.

\begin{tabular}{|c|c|c|c|}
\hline & \multicolumn{3}{|l|}{ Desalination plant } \\
\hline & D-1 & D-2 & D-3 \\
\hline $\begin{array}{l}\text { Exploited } \\
\text { aquifer }\end{array}$ & $\begin{array}{l}\text { Quaternary \& } \\
\text { Pliocene (alluvium } \\
\text { \& sandstone) }\end{array}$ & $\begin{array}{l}\text { Messinian } \\
\text { (sandstone, sand, } \\
\text { clays (north)) }\end{array}$ & $\begin{array}{l}\text { Tortonian } \\
\text { (conglomerates and } \\
\text { sandstone) }\end{array}$ \\
\hline Well depth (m) & 150 & 350 & $600^{\mathrm{c}}$ \\
\hline $\begin{array}{l}\text { Groundwater } \\
\text { salinity }(\mu \mathrm{S} / \mathrm{cm})\end{array}$ & $6000-9000^{\mathrm{a}}$ & $4000-6000^{\mathrm{a}}$ & 6000 \\
\hline $\begin{array}{l}\text { Year of } \\
\text { construction } \\
\text { (year) }\end{array}$ & $1995^{\mathrm{b}}$ & 2000 & 2000 \\
\hline $\begin{array}{l}\text { Desalinated } \\
\text { volume } \\
\left(\mathrm{m}^{3} / \text { day }\right)\end{array}$ & 110 & 120 & 140 \\
\hline $\begin{array}{l}\text { Rejected brine } \\
(\%)\end{array}$ & $25 \%$ & $25 \%$ & $25 \%$ \\
\hline $\begin{array}{l}\text { Irrigated land } \\
\text { (ha) }\end{array}$ & 60 & 115 & 100 \\
\hline
\end{tabular}

a Average of two pumping wells with different salinity.

b Year of construction coincides with a severe drought.

${ }^{\mathrm{c}}$ Depth was initially $300 \mathrm{~m}$, and is currently $600 \mathrm{~m}$ after redrilling.

Table 2

Cost of desalinated groundwater in the D-1, D-2, and D-3 small desalination plants. Campo de Cartagena, 2015 data.

\begin{tabular}{llll}
\hline & $\mathrm{D}-1$ & $\mathrm{D}-2$ & $\mathrm{D}-3$ \\
\hline Investment cost $(€)$ & 240,000 & 220,000 & 250,000 \\
Depreciation period (years) & 25 & 25 & 25 \\
Interest $(\%)$ & 4 & 4 & 4 \\
Production $\left(\mathrm{m}^{3} /\right.$ day) & 110 & 120 & 140 \\
Price of energy $(€ / \mathrm{kWh})$ & 0.048 & 0.048 & 0.048 \\
Energy consumption $\left(\mathrm{kWh} / \mathrm{m}^{3)}\right.$ & 2.25 & 2.45 & 2.82 \\
Electrical energy $\left(€ / \mathrm{m}^{3}\right)$ & 0.108 & 0.1176 & 0.13536 \\
Personnel $\left(€ / \mathrm{m}^{3}\right)$ & 0.01 & 0.01 & 0.01 \\
Chemical products $\left(€ / \mathrm{m}^{3}\right)$ & 0 & 0.1 & 0.09 \\
Maintenance and others $\left(€ / \mathrm{m}^{3}\right)$ & 0.12 & 0.08 & 0.12 \\
Replacement of membranes $\left(€ / \mathrm{m}^{3}\right)$ & 0.013 & 0.013 & 0.013 \\
Total cost without depreciation $\left(€ / \mathrm{m}^{3}\right)$ & 0.25 & 0.32 & 0.37 \\
Total cost with depreciation $\left(€ / \mathrm{m}^{3}\right)^{\mathrm{a}}$ & 0.57 & 0.61 & 0.70 \\
\hline
\end{tabular}

a Estimates for IC at each plant. 
The final cost of water, after mixing desalted water with water from another origin (Tajo-Segura transfer, groundwater and desalinated seawater) for citrus irrigation are in Table 3 . The water finally applied for irrigation in the different plants was composed of $70 \%$ desalinated water and $30 \%$ of water transfer at D-1; $70 \%$ desalinated water and 30\% groundwater for D-2, and in D-3 by $70 \%$ desalinated water and $30 \%$ desalinated seawater. The cheapest final cost of water for irrigation corresponds to D-1, a mixture with the Tajo-Segura water transfer, considering an average cost of transferred water of $0.17 € / \mathrm{m}^{3}$ for the study period. Being the cost for groundwater the cost $0.18 € / \mathrm{m}^{3}$ and $0.58 € / \mathrm{m}^{3}$ for seawater desalination.

The benefits (SPC, Eq. 5) obtained for 2015, after considering the citrus production $(\mathrm{kg} / \mathrm{ha})$, the average price for the 1998-2004 period and by assuming that cultivated orchards were in full production, are presented in Table 4.

\subsection{Results of the NPV, IRR, BCr and sensitivity analyses}

The obtained $N P V$ (Eq. 2), IRR (Eq. 4) and $B C r$ (Eq. 3) are presented in Table 5. According to the results, project management was profitable for the three cases: the $N P V$ is positive and the Cost/benefit ratio $(B C r)$ is $>1$. The $I R R$ is also positive and higher than $11 \%$. According to Table 6, D-2 plant was the most profitable project with the best results for NVP, IRR and $C B r$, which could be due to the lower salinity of desalted groundwater $(4000-600 \mu \mathrm{S} / \mathrm{cm})$ compared with the other two plants.

Usually, in desalination plant projects management, decision makers are faced with multiple alternatives that can be adopted, but available funds are limited. Whenever there are several alternatives with a positive $N P V$, even though it cannot be feasibly undertaken, it would be convenient to prioritize them to maximize the returns to available

Table 3

Total cost of water for citrus irrigation after mixing desalted water with water from other origins (considering plant depreciation, Table 2).

\begin{tabular}{llll}
\hline & $\mathrm{D}-1^{\mathrm{a}}$ & $\mathrm{D}-2^{\mathrm{b}}$ & $\mathrm{D}^{\mathrm{c}}$ \\
\hline Desalinated volume $\left(\mathrm{m}^{3} /\right.$ year $)$ & 165,480 & 317,170 & 275,800 \\
Irrigated area (ha) & 60 & 115 & 100 \\
Total water volume (mixed, $\mathrm{m}^{3} /$ year) & 236,400 & 453,100 & 394,000 \\
Final total cost $(€ /$ year) & 106,380 & 217,941 & 261,616 \\
\hline
\end{tabular}

${ }^{a}$ Mixing with water transfer.

${ }^{b}$ Mixing with groundwater.

c Mixing with desalinated seawater.

Table 4

Gross production of citrus for the orchards at the three studied sites (2015 data).

\begin{tabular}{lllll}
\hline Plant & $\begin{array}{l}\text { Irrigated area } \\
(\text { ha })\end{array}$ & $\begin{array}{l}\text { Average price } \\
(€ / \mathrm{kg})^{\mathrm{a}}\end{array}$ & $\begin{array}{l}\text { Average production } \\
(\mathrm{kg} / \mathrm{ha})\end{array}$ & $\begin{array}{l}\text { Gross } \\
\text { production } \\
\left(€ \times 10^{3}\right)\end{array}$ \\
\hline $\mathrm{D}-1$ & 60 & 0.25 & 35,000 & 525,000 \\
$\mathrm{D}-2$ & 115 & 0.25 & 38,000 & 1,092000 \\
$\mathrm{D}-3$ & 100 & 0.25 & 40,000 & 1000,000 \\
\hline
\end{tabular}

${ }^{a}$ Data provided by IMIDA, the price of citrus is variable along year; an average price has been calculated.

Table 5

Estimation of Net Present Value (NPV), Internal Rate of Return (IRR) and Benefit/Cost ratio $(\mathrm{BCr})$ in the three plants.

\begin{tabular}{llll}
\hline & D-1 & D-2 & D-3 \\
\hline NPV $(€)$ & $2,101,631$ & $6,065,281$ & $5,999,774$ \\
$\operatorname{IRR}(\%)$ & 11 & 16 & 16 \\
BCr & 1.3 & 1.5 & 1.4 \\
\hline
\end{tabular}

Table 6

Sensitivity analysis results $(N P V)$ for the final cost of desalinated water between 0.57 and $3 € / \mathrm{m}^{3}$.

\begin{tabular}{llll}
\hline Cost of mixed water $\left(€ / \mathrm{m}^{3}\right)$ & $\begin{array}{l}\mathrm{D}-1(€) \\
N P V\end{array}$ & $\begin{array}{l}\mathrm{D}-2(€) \\
N P V\end{array}$ & $\begin{array}{l}\mathrm{D}-3(€) \\
N P V\end{array}$ \\
\hline 0.57 & 174,173 & & \\
0.61 & 173,757 & 429,061 & \\
0.70 & 152,245 & 408,833 & 422,117 \\
0.80 & 135,697 & 386,178 & 393,992 \\
0.90 & 119,149 & 363,523 & 366,412 \\
1.00 & 102,601 & 340,868 & 338,832 \\
1.50 & $\mathbf{1 9 , 8 6 1}$ & 227,593 & 200,932 \\
2.00 & $-62,879$ & 114,318 & $\mathbf{6 3 , 0 3 2}$ \\
2.50 & $-145,619$ & $\mathbf{1 0 4 3}$ & $-74,868$ \\
3.00 & $-228,359$ & $-112,232$ & $-212,768$ \\
\hline
\end{tabular}

funds. The $B C r$ estimation offers a noteworthy advantage, together with one primary disadvantage, compared with the $N P V$.

According to the sensitivity analysis results (Table 6), an increase in the water production cost adversely affects the project's profitability, which makes the NPV negative at certain water cost values. An increase in the cost per $\mathrm{m}^{3}$ could be due to different factors such as increasing the plant's operational costs, changes in electricity tariff, personnel costs, variation of aquifer salinity, a drop in the groundwater level, etc. The results show that D-2 plant appears to be the most profitable management option still involving benefits for high costs $\left(2.5 € / \mathrm{m}^{3}\right)$.

There are parameters (not considered herein) that could generate significant changes in the final cost of the desalinated water as brine discharge, elimination of waste, environmental noise pollution, etc. And could also directly affect the $N P V$, however, an increase in cost $\left(\right.$ per $\mathrm{m}^{3}$ ) when taking into account these variables continued to leave the three plants within the permissible exploitation limit as the analysis included quite a flexible range.

\section{Conclusions}

Generally for small desalination plants costs and benefits are not correctly estimated, the main reason being that (positive or negative) externalities are not usually considered. Our results indicate that agricultural management is feasible for the three studied cases, and costs outweigh benefits for citrus cultivation. However, when the price is raised by between 2 and $2.5 € / \mathrm{m}^{3}$, which is far below the average price $\left(0.57-0.70 € / \mathrm{m}^{3}\right)$, the $N P V$ becomes negative. The outputs indicate that the final cost is highly dependent on the source of water used for the final mixing. Mixing with Tajo-Segura water transfer appears to be the most profitable management option, and according to the sensitivity analysis the most profitable is the D-2 plant, evidenced herein.

This research provides evidence of practical and theoretical implications as to how to increase water resources in areas with scarce water by closing the loop concept in a moving circular economy, while ensuring farmers' profitability and encouraging private sector investments. It proves to be an interesting application to asses' water management economic feasibility in similar areas were water is scarce. Using brackish desalinated water to increase available water resources is a key issue for the IWRM, but the most suitable selection requires assessing the economic beneficial or adverse effects.

\section{Acknowledgements}

This research constitutes a specific application of a more comprehensive study (CGL2013-48802-C3-3-R research project) financed by the Ministerio de Economía y Competitividad of Spain. The au- 
thors also acknowledge Mr. A. Marín for his cooperation in conducting the study.

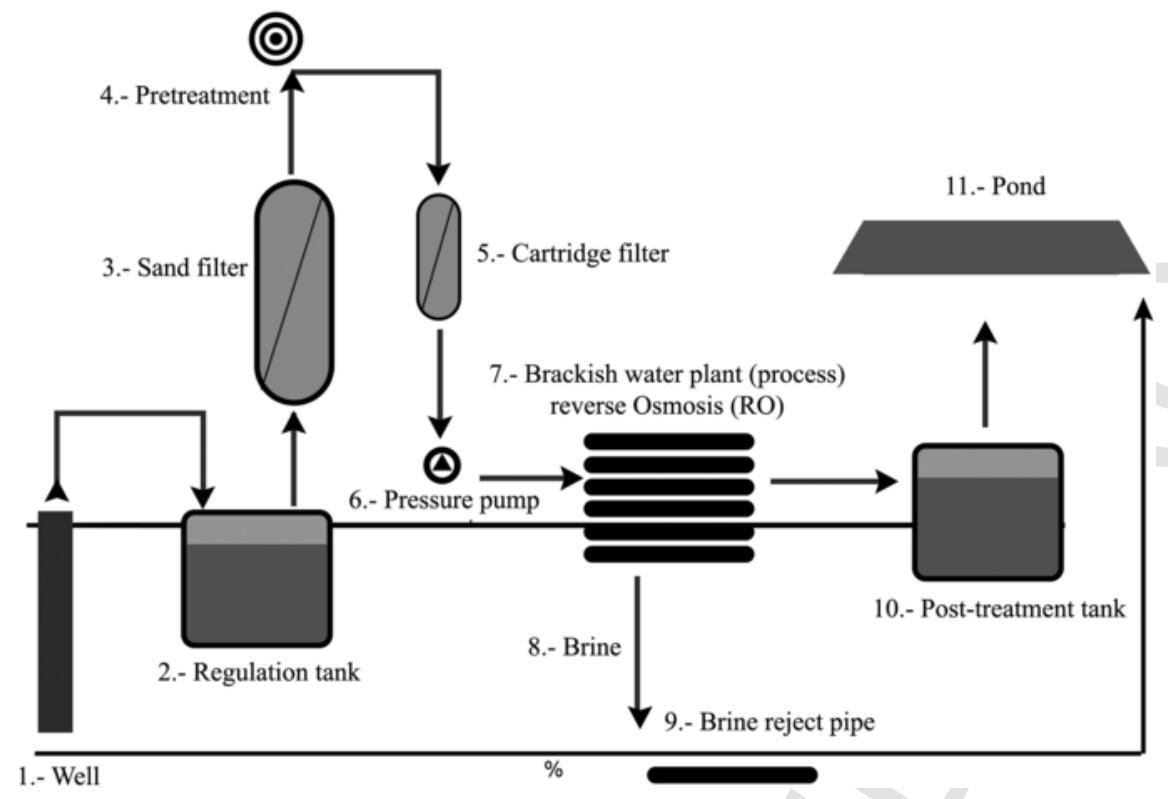

Fig. 4. Sketch of the small plants used for the agricultural management of Campo de Cartagena. 


\section{References}

[1] EU, Report on the Review of the European Water Scarcity and Droughts Policy, In: Communication from the Commission to the European Parliament and the Council, The Eur. Econ. And Soc. Comm. and the Comm. of the Reg., DG Environ., Brussels, 2012

[2] E. Custodio, J.M. Andreu-Rodes, R. Aragon, T. Estrela, J. Ferrer, J.L. Garcia-Arostegui, Groundwater intensive use and mining in south-eastern peninsular Spain: Hydrogeological, economic and social aspects, Sci. Total Environ. 559 (2016) 302-316, http://dx.doi.org/10.1016/j.scitotenv.2016.02.107.

[3] MED WS\&D WG, Mediterranean water scarcity and drought report, In: Mediterranean Water Scarcity \& Drought Working Group, European Commission Technical Report, 2017, pp. 009-2007. www.emwis.net/topics/ WaterScarcity.

[4] MMA, Memoria ambiental comparativa entre las actuaciones urgentes en las cuencas del Mediterráneo y la alternativa al proyecto de transferencias autorizadas por el artículo 13 de la Ley 10/2001, de 5 de julio, del Plan Hidrológico Nacional, Secretaría General para el Territorio y la Biodiversidad, Madrid, 2014. 29 pp..

[5] V. Martínez-Álvarez, B. Martin-Gorriz, M. Soto-García, Seawater desalination for crop irrigation a review of current experiences and revealed key issues, Desalination 381 (2016) 58-70, http://dx.doi.org/10.1016/j.desal.2015.11.032.

[6] E. Feitelson, G. Rosenthal, Desalination, space and power: the ramifications of Israel's changing water geography, Geoforum 43 (2012) 272-284, http://dx.doi. org/10.1016/j.geoforum.2011.08.011.

[7] M.A. Shannon, P.W. Bohn, M. Elimelech, J.G. Georgiadis, B.J. Mariñas, A.M. Mayes, Science and technology for water purification in the coming decades, Nature 452 (2008) 301-310, http://dx.doi.org/10.1038/NATURE06599.

[8] C. Garcia, F. Molina, D. Zarzo, 7-year operation of a BWRO plant with raw water from a coastal aquifer for agricultural irrigation, Desalin. and Water Treat. 31 (2011) 331-338, http://dx.doi.org/10.5004/DWT.2011.23.

[9] O. Barron, R. Ali, G. Hodgson, D. Smith, E. Qureshi, D. McFarlane, E. Campos, D. Zarzo, Feasibility assessment of desalination application in Australian traditional agriculture, Desalination 364 (2015) 33-45, http://dx.doi.org/10. 1016/j.desal.2014.07.024.

[10] J. Valdés-Abellan, J. Jiménez-Martínez, L. Candela, HYDRUS application to assess possible impacts of non-conventional water irrigation under two different vadose zone monitoring strategies, In: Proceedings of the 4th International Conference HYDRUS Software Applications to Subsurface Flow and Contaminant Transport Problems, 2013. March 21-22.

[11] J.L. Jiménez-Martínez, J.L. García-Aróstegui, S. Hunink, P. Contreras, L. Baudron, L. Candela, The role of groundwater in highly human-modified hydrosystems: a review of impacts and mitigationoptions in the Campo de Cartagena-Mar Menor coastal plain (SE Spain), Environ. Rev. 24 (4) (2016) 377-392, http://dx.doi.org/10.1139/er-2015-0089.

[12] J. Aparicio, O. Alfranca, J. Jimenez-Martinez, J.L. Garcia-Arostegui, L. Candela, J.L. Lopez, Groundwater salinity process, mitigation measures and economic assessment: an example from an intensive agricultural area, In: 42nd IAH Congress, 2015, p. 290. 13-18 September). Rome, Italy. (Abstract Book).

[13] S. Al-Hengari, M. El-Bousiffi, W. El-Mudir, Performance analysis of a MSF desalination unit, Desalination 182 (1) (2005) 73-85. http://dx.doi.org/10.1016/ j.desal.2005.03.010.

[14] I.C. Karagiannis, P.G. Soldatos, Water desalination cost literature: review and assessment, Desalination 223 (2008) 448-456. http://dx.doi.org/10.1016/j.desal. 2007.02.071.

[15] CHS, Plan Hidrologico de la Cuenca del Segura, 2014, 2009/2015. Murcia, Spain.

[16]

[17] M. Soto-Garcia, V. Martinez-Alvarez, P.A. Garcia-Bastida, F. Alcon, B. Martin-Gorriz, Effect of water scarcity and modernization on the performance of irriga- tion districts in south-eastern Spain, Agric Water Manag 124 (2014) 11-19, http://dx.doi.org/10.1016/j.agwat.2013.03.019.

[18] J. Jiménez-Martínez, L. Candela, J.L. García-Aróstegui, R. Aragón, A 3D geological model of Campo de Cartagena, SE Spain: Hydrogeological implications. 10 (2) (2012) 1-13, http://dx.doi.org/10.1344/105.000001703.

[19] A.W. Olivieri, J.A. Sollera, K.J. Olivieri, R.P. Goebel, G. Tchobanoglous, Seasonal tertiary wastewater treatment in California: an analysis of public health benefits and costs, Water Res. 39 (2005) 3035-3043, http://dx.doi.org/10.1016/ j.watres.2005.05.010.

[20] G. Ahmad, J. Schmid, Feasibility study of brackish water desalination in the Egyptian deserts and rural regions using PV systems, Energ. Conver. Manage. 43 (2002) 2641-2649. http://dx.doi.org/10.1016/S0196-8904(01)00189-3.

[21] E. Chatzisymeon, Reducing the energy demands of wastewater treatment through energy recovery, in: K.P. Tsagarakis, K. Stamatelatou (Eds.), Sewage Treatment Plants, Economic Evaluation of Innovative Technologies for Energy Efficiency, IWA Publishing, 2015.

[22] M. Molinos-Senante, A. Maziotis, R. Sala-Garrido, Estimating the cost of improving service quality in water supply: a shadow price approach for England and Wales, Sci. Total Environ. 539 (2016) 470-477.

[23] M. Benedetti, D. Bixio, P.A. Vanrolleghem, Benchmarking of WWTP design by assessing costs effluent quality and process variability, Water Sci. Technol. 54 (2006) 95-102, http://dx.doi.org/10.2166/wst.2006.809.

[24] R. Chen, C. Wang, Cost-benefit evaluation of a decentralized water system for wastewater reuse and environmental protection, Water Sci. Technol. 59 (2015) 1515-1522, http://dx.doi.org/10.2166/wst.2009.156.

[25] M. Molinos-Senante, F. Hernández-Sancho, M. Mocholí-Arce, R. Sala-Garrido, Productivity growth of wastewater treatment plants - accounting for environmental impacts: a Malmquist-Luenberger index approach, Urban Water J 13 (5) (2015) 476-485. doi.org/10.1080/1573062X.2014.994000.

[26] N. Hanley, E.B. Barbier, Pricing Nature: Cost-Benefit Analysis and Environmental Policy-Making, 1London 12009.

[27] R.O. Zerbe, A.S. Bellas, A Primer for Benefit-Cost Analysis, Edward Elgar Publishing, 2006.

[28] T. Younos, Environmental issues of desalination, J Contemp. Water Res Educ. 132 (2005) 11-18, http://dx.doi.org/10.1111/j.1936-704X.2005. mp132001003.x.

[29] M. Torres, Avances tecnológicos y costes de la desalación, Ponencia presentada en las Jornadas Técnicas sobre la desalación en el Programa AGUA. Grupo Recoletos, Madrid, Octubre, 2004.

[30] J.E. Miller, Review of Water Resources and Desalination Technologies, in: Report 2003-0800, 54, Sandia National Laboratories 2003.

[31] G. Rachid, M. El Fadel, M. Al Hindi, I. Jamali, D. Abdel Nour, Indirect Solar Desalination: Value Engineering and Cost Benefit Analysis, In: World Academy of Science, Engineering and Technology, International Journal of Electrical, Computer, Energetic, Electronic and Communication Engineering, 9,2015 , pp. $520-526$.

[32] I.S. Jaber, M.R. Ahmed, Technical and economic evaluation of brackish ground-water desalination by reverse osmosis (RO) process, Desalination 165 (2004) 209-213. http://dx.doi.org/10.1016/j.desal.2004.06.051.

[33] M.A. Jones, I. Odeh, M. Haddad, A.H. Mohammad, J.C. Quinn, Economic analysis of photovoltaic (PV) powered water pumping and desalination without energy storage for agriculture, Desalination 387 (2016) 35-45, http://dx.doi.org/ 10.1016/j.desal.2016.02.035.

[34] A. Al-Karaghouli, L. Kazmerski, Energy consumption and water production cost of conventional and renewable-energy-powered desalination processes, Renew. Sustain. Energy Rev. 24 (2013) 343-356, http://dx.doi.org/10.1016/j.rser. 2012.12.064.

[35] A. Hafez, S. El-Manharawy, Economics of seawater RO desalination in the Red Sea region, Egypt. Part 1. A case study, Desalination 153 (2002) 335-347. http: //dx.doi.org/10.1016/S0011-9164(02)01122-0. 